\title{
Food-borne bacterial pathogens in marketed raw meat of Dharan, eastern Nepal
}

\author{
Kamana Bantawa ${ }^{1 *} \mathbb{D}$, Kalyan Rai ${ }^{1}$, Dhiren Subba Limbu² and Hemanta Khanal'
}

\begin{abstract}
Objectives: This study aims to assess the bacteriological quality of marketed raw meat with a special emphasis on isolation of Escherichia coli, Salmonella spp., Shigella spp., Vibrio spp., Pseudomonas aeruginosa and Staphylococcus aureus in raw meat marketed in Dharan. Altogether 50 meat samples were collected from local markets of Dharan and transported to the microbiology laboratory at $4^{\circ} \mathrm{C}$. The meat samples were homogenized in a sterile glass homogenizer and the possible pathogens were isolated and identified by conventional microbiological techniques.

Results: The mean total viable count values were found having a mean count of $8.22 \pm 0.14,8.29 \pm 0.17,7.87 \pm 0.18$ and $7.92 \pm 0.19$ in terms of $\log _{10} \mathrm{CFU} / \mathrm{g} \pm$ Standard Error for chicken, pork, buffalo, and goat meat respectively. Coliforms were found in $84 \%$ samples, S. aureus was found in 68\% samples, Salmonella spp. in 34\% samples, Shigella spp. in $6 \%$ samples, Vibrio spp. in only 3 samples and P. aeruginosa was isolated from $40 \%$ sample. Higher microbial load and presence of intestinal commensals E. coli, Salmonella spp., Shigella spp., Vibrio spp indicates that meat might be contaminated by the visceral content and consumers are at risk of getting a foodborne disease when eaten raw.
\end{abstract}

Keywords: Meat, Total viable count, Coliforms, Dharan

\section{Introduction}

The term meat refers to the flesh, skeletal muscle and any attached connective tissue or fat excluding bone and bone marrow [1]. Meat is a good source of protein, essential fatty acids, minerals and vitamins but easily perishable because it provides the suitable medium for the growth of various microorganisms [1,2]. The muscles of healthy animals contain less or nil microorganisms though, meat can be contaminated during slaughtering and transportation [3]. Contamination of raw meat easily occurs from external sources during bleeding, handling, and processing via knives, tools, clothes, hands, and air [4]. The contaminated meat and meat products readily cause a variety of biological, chemical, physical, and particularly microbial food hazards $[5,6]$. The extent of microbial contamination and composition of microbial flora reflect the standard hygiene of meat [7].

\footnotetext{
*Correspondence: kamnarai5@gmail.com

1 Department of Microbiology, Central Campus of Technology, Tribhuvan University, Dharan, Nepal

Full list of author information is available at the end of the article
}

Foodborne pathogens are the leading causes of illness and death in less developed countries [8]. Nearly 1.4 million cases are caused by nontyphoidal Salmonella serotypes and 270,000 cases are caused by pathogenic Escherichia coli, including E. coli O157: $\mathrm{H} 7[7,8]$. Although these pathogens usually cause self-limiting gastroenteritis, invasive diseases and complications also may occur. Similarly, systemic Salmonellosis infections can be life-threatening, and Shiga toxin-producing E. coli, particularly E. coli O157: H7, can cause bloody diarrhoea and hemolytic uremic syndrome [9].

Nowadays, the awareness has been growing on the public health impact of zoonotic foodborne pathogens transmitted from animal originated food [10]. The most important foodborne bacterial pathogens associated with meat are Salmonella spp., Staphylococcus aureus, Escherichia coli, Campylobacter jejuni, Listeria monocytogenes, Clostridium perfringes, Yersinia enterocolitica and Aeromonas hydrophila [11]. Among them, Salmonella species, Campylobacter jejuni, Listeria monocytogenes and verocytotoxin producing $E$. coli $\mathrm{O} 157$ are a major public health problem [9]. Additionally, Pseudomonas species are associated with spoilage of meat causing off-odours, 
off-flavours, discolouration and gas production [12, 13]. Similarly, Vibrio species are the leading cause of gastroenteritis, wound infection and septicemia in human [14, $15]$.

The marketed raw meat is available with objectionable hygiene and in the open air without adequate temperature control in Nepal. The present study was done to determine the prevalence of foodborne pathogens with special emphasis on Salmonella spp., Staphylococcus aureus, Escherichia coli and Vibrio spp. in marketed raw meat available in Dharan, eastern Nepal.

\section{Main text Methods Study site}

The study area is a city of Province No. 1 of Nepal and located in foothills of Mahabharat range in the north and Terai region in the south at the altitude of 349 meters. It is a trade centre between the hilly region and terai plains of eastern development region. The per capita meat consumption in Dharan is comparatively higher i.e. $13 \mathrm{~kg}$ whereas national per capita meat consumption is only $9 \mathrm{~kg}$.

\section{Analytical methods}

A cross-sectional study was carried out in 6 months from January to June 2017 focusing on retail meat shops of Dharan city. A total of 50 (15 chicken, 15 pork, 10 buffalo and 10 goat meat) samples were collected. A sample of $250 \mathrm{~g}$ was collected in a sterile plastic bag and transported to the laboratory maintaining cold chain. The samples were collected at 7-9 a.m. Samples were processed immediately as soon as possible otherwise preserved at $4{ }^{\circ} \mathrm{C}$.

Along with sample collection and homogenization, all of the analyses including total viable count (TVC), total coliform count (TCC), isolation of E. coli, Salmonella spp., Shigella spp., Vibrio spp., Staphylococcus aureus and Pseudomonas spp. were done as described by U.S. FDA guideline of bacteriological analytical methods for food samples [16]. The triplicate plate cultures were prepared for all tests performed and all of the culture media were used supplied from Himedia, India. Obtained isolates were identified by cultural characteristics, Gram staining, and biochemical tests as described by Bergey's Manual of Determinative Bacteriology [17].

For statistical analysis, data obtained were tabulated with Microsoft Office Excel 2007 and analyzed with SPSS version 23. Chi square test was used to determine the significant association of dependent variables at $5 \%$ level of significance.

\section{Results and discussions}

The mean value of TVC and TCC of raw meat is presented in Table 1 . The mean TVC value was slightly higher in chicken $\left(\log _{10} 8.22 \pm 0.14 \mathrm{CFU} / \mathrm{g}\right)$ and pork $\left(\log _{10} 8.29 \pm 0.17 \mathrm{CFU} / \mathrm{g}\right)$ in compared to buffalo ( $\log _{10}$ $7.87 \pm 0.18 \mathrm{CFU} / \mathrm{g})$ and goat $\left(\log _{10} 7.92 \pm 0.19 \mathrm{CFU} / \mathrm{g}\right)$.

Results revealed that the highest TVC was found in pork sample and the lowest TVC was found in buffalo meat sample. The microbiological condition of fresh raw meat of local market of Dharan can be assumed to be heavily contaminated with spoilage and pathogenic organisms. In the case of coliforms, the lowest TCC was found in pork meat $(6.16 \pm 0.92 \mathrm{CFU} / \mathrm{g})$ and the highest coliform count was found in chicken meat $(8.13 \pm 0.13 \mathrm{CFU} / \mathrm{g})$. From statistical analysis, a significant association between the type of meat and the coliform count was not observed $(P>0.05)$.

Total viable count was found to be higher in almost all of the samples than the inspected German Quality meat standards, microbiological standards of Europe and United States, EU microbiological standard of cut meat and Oregon state microbiological standard for fresh meat. The result obtained was also higher than guideline by ISO, being followed by Nepal, which has set 105-107 total viable count and absence of coliforms in $0.01 \mathrm{~g}$ of raw meat and $\leq 104$ total viable counts and absence of coliforms in $0.01 \mathrm{~g}$ for pre-cooked meat. The reason behind the higher prevalence rates could be could be related to the difference in time and season of research.

Table 2 illustrated that the prevalences of different bacterial pathogens. The highest prevalence of Salmonella spp., E. coli, and P. aeruginosa were found in chicken meat. Neither of chicken meat was contaminated with Vibrio spp. and neither of buffalo meat was contaminated with Shigella spp. From the statistical analysis, it can be concluded that there was no significant relationship between the type of meat and the presence of $S$. aureus $(\mathrm{P}>0.05)$, E. coli $(\mathrm{P}>0.05)$, Shigella $(\mathrm{P}>0.05)$, Vibrio $(\mathrm{P}>0.05)$ and $P$. aeruginosa $(\mathrm{P}>0.05)$. However, there was a significant association between the type of meat and Salmonella spp. $(\mathrm{P}<0.05)$.

In this study, S. aureus was found in $68 \%$ samples. This prevalence is higher than previous researches by Tassew

Table 1 Mean total counts of raw meat in $\log _{10}$ CFU per gram \pm standard error (SE)

\begin{tabular}{lcc}
\hline Sample $(\mathbf{n}=\mathbf{5 0})$ & Mean TVC & Mean TCC \\
\hline Chicken $(n=15)$ & $8.22 \pm 0.14$ & $8.13 \pm 0.13$ \\
Pork $(n=15)$ & $8.29 \pm 0.17$ & $6.16 \pm 0.92$ \\
Buffalo $(n=10)$ & $7.87 \pm 0.18$ & $6.31 \pm 1.06$ \\
Goat $(n=10)$ & $7.92 \pm 0.19$ & $6.37 \pm 1.07$ \\
\hline
\end{tabular}


Table 2 Prevalence of pathogens in raw meat

\begin{tabular}{lllllll}
\hline Type of meat & \multicolumn{2}{l}{ Prevalence of pathogens (\%) } & & \\
\cline { 2 - 7 } & S. aureus & E. coli & Salmonella spp. & Shigella spp. & Vibrio spp. & P. aeruginosa \\
\hline Chicken $(n=15)$ & 53.33 & 66.6 & 60 & 4 & 0 & 46.66 \\
Pork $(n=15)$ & 73.33 & 60 & 10 & 0 & 2 & 40 \\
Buffalo $(n=10)$ & 80 & 40 & 20 & 2 & 2 & 40 \\
Goat $(n=10)$ & 70 & 46.7 & 33.3 & 0 & 2 & 33.33 \\
Total $(N=50)$ & 68 & 54 & 34 & 6 & 6 & 40 \\
P-value & 0.501 & 0.527 & 0.047 & 0.346 & 0.674 & 0.708 \\
\hline
\end{tabular}

et al. in Ethiopia in 2010 and Abdalrahman et al. in beef $[18,19]$. The prevalence of $S$. aureus was also greater than the study of Rong et al. in retail foods of China [20]. The higher prevalence of $S$. aureus indicates that inadequate cleaning, unsatisfactory handling, and post-processing contamination from the polluted atmosphere around shops. High prevalence of $S$. aureus in raw meat and handlers contain health hazards like toxin-mediated virulence and invasiveness to consumers [21]. These higher prevalence rates could be due to hand evisceration technique and inadequate hand washing.

As an indicator of hygiene and sanitary quality, the presence of $E$. coli suggests that consumers are at risk of being food poisoned and the presence of other pathogenic flora [22]. E. coli was found in 54\% of the total samples. The prevalence of $E$. coli was also higher than in previous studies of Roades et al. in 2008, Lee et al. in 2006-2012 and Rontsiou et al. in 2012 [23-25].

Another potential pathogen Salmonella spp. was found in $34 \%$ of total samples which is higher than previous studies by Tassew et al. in 2010 and Garedew et al. in 2015 [14, 18]. The prevalence of Salmonella spp. in meat was beyond the EU Microbiological standards of cut meat for sale and further processing according to which Salmonella. Differences in prevalence rates from this study to another might be attributed to the unhygienic processing and poor sanitation of meat shops. It showed that meat retailers were found to be unaware of the basic requirements of basic guidelines regarding meat. It had been proved that direct contact with raw meat might pose health hazards to humans especially butchers because E. coli, Salmonella, Shigella and Vibrio are transmitted via the faecal-oral route.

Shigella spp. were found in $6 \%$ samples which is higher than the research by Tassew et al. in which it was found in only $0.6 \%$ samples but lower than Garedew et al. in 2016 in Ethiopia [14, 26]. Similarly, Vibrio spp. were also found in $6 \%$ samples which is lower than the research by Lopatek et al. in 2015 and Yucel et al. in 2010 in marine seafood [27, 28]. Pseudomonas aeruginosa was isolated from $40 \%$ sample which was comparable to findings of researches by Kwan et al., Gennari et al., Arnautet al., and Elmanhdi et al. at different dates and locations [29-32]. Higher prevalence of Pseudomonas aeruginosa indicates the post-processing contamination and meat are prone to spoilage. The presence of different pathogens in examined samples represents a great public health risk. Our results concluded that the cross-contamination occurs from the raw meat to handlers to consumers.

\section{Conclusions}

All the meat samples were found to contain higher microbial load than prescribed standards. This study showed that $68 \%$ of samples were contaminated with S. aureus, $54 \%$ samples with E. coli, 34\% samples with Salmonella spp., 40\% of samples with Pseudomonas spp. and 6\% samples with Vibrio spp. and Shigella spp. Presence of intestinal commensals E. coli, Salmonella spp., Shigella spp., Vibrio spp. indicates the alarming public health concerns, which needs to be studied in larger contexts to identify the source of contamination. This study also revealed that unhygienic processing and poor sanitation of meat shops and meat retailers were unaware of basic requirements and guidelines of meat shop. To upgrade the quality of raw meat, routine monitoring of meat shops, implementation of Animal Slaughter and Meat Inspection Act 2055 and awareness campaign for the butchers and consumers should be done.

\section{Limitations}

Confirmation of bacteria by molecular methods was not performed. Similarly, serotyping of isolated pathogens were not done. Antibiotics susceptibility patterns of isolates were not examined.

\section{Abbreviations}

CFU: colony forming unit; FDA: Food and Drug Administration; SE: standard error; TVC: total viable count; TCC: total coliform count. 


\section{Authors' contributions}

KB participated in study design, sample collection, processing, bacterial culture, data analysis and preparing the manuscript. DSL participated in sample collection, processing and bacterial identification. KR participated in data analysis and interpretation. HK participated in bacterial culture, identification and assisted in manuscript preparation. All authors read and approved the final manuscript.

\section{Author details}

${ }^{1}$ Department of Microbiology, Central Campus of Technology, Tribhuvan University, Dharan, Nepal. ${ }^{2}$ Department of Microbiology, Birendra Memorial College, Tribhuvan University, Dharan, Nepal.

\section{Acknowledgements}

We are thankful to the butchers for co-operation and Department of Microbiology, Central Campus of Technology, Tribhuvan University, Dharan for their technical support.

\section{Competing interests}

The authors declare that they have no competing interests.

\section{Availability of data and materials}

All the required data and materials are provided in the manuscript.

\section{Consent for publication}

Not applicable.

\section{Ethics approval and consent to participate}

This study was carried out as a part of the Thesis of Master of Science (M.Sc.) Microbiology and approved by Department of Microbiology, Central Campus of Technology. Consents of retail shopkeepers were taken orally before collecting samples.

\section{Funding}

None to declare. This research was carried out from the financial assistance provided by University Grant Commission, Nepal for the Masters Research Support Grant.

\section{Publisher's Note}

Springer Nature remains neutral with regard to jurisdictional claims in published maps and institutional affiliations.

Received: 3 July 2018 Accepted: 20 August 2018

Published online: 29 August 2018

\section{References}

1. Williams P. Nutritional composition of red meat. Nutr Diet. 2007;64:S1139. https://doi.org/10.1111/j.1747-0080.2007.00197.x.

2. Komba EV, Komba EV, Mkupasi EM, Mbyuzi AO, Mshamu S, Mzula A, Luwumba D. Sanitary practices and occurrence of zoonotic conditions in cattle at slaughter in Morogoro Municipality, Tanzania: implications for public health, Tanzan. J Health Res. 2012;14:1-12.

3. Ercolini D, Russo F, Torrieri E, Masi P, Villani F. Changes in the spoilagerelated microbiota of beef during refrigerated storage under different packaging conditions. Appl Environ Microbiol. 2006;72:4663-71. https:// doi.org/10.1128/AEM.00468-06.

4. Eisel WG, Linton RH, Muriana PM. A survey of microbial levels for incoming raw beef, environmental sources, and ground beef in a red meat processing plant. Food Microbiol. 1997;14:273-82. https://doi.org/10.1006/ fmic 1996.0094.

5. Kim HJ, Kim D, Song SO, Goh YG, Jang A. Microbial status and guideline for raw chicken distributed in Korea. Korean J Poult Sci. 2016:43:235-42. https://doi.org/10.5536/KJPS.2016.43.4.235.

6. Ko EK, Heo EJ, Kim YJ, Park HJ, Wee SH, Moon JS. Evaluation of microbiological contamination level of raw beef from retail markets in Seoul, Korea. Korean J Food Sci Anim Resour. 2013:33:403-10. https://doi. org/10.5851/kosfa.2013.33.3.403.
7. Blaser MJ. Epidemiologic and clinical features of Campylobacter jejuni infections. J Infect Dis. 1997;176(Suppl. 2):S103-5.

8. Mead PS, Slutsker L, Dietz V, McCaig LF, Bresee JS, Shapiro C, Griffin PM, Tauxe RV. Food-related illness and death in the United States. Emerg Infect Dis. 1999:5:607-25.

9. Griffin PM. Escherichia coli O157: H7 and other enterohemorrhagic Escherichia coli. In: Blaser MJ, Smith PD, Ravdin JI, Greenberg $H B$, Guerrant RL, editors. Infections of gastrointestinal tract. New York: Raven Press; 1995. p. 739-61.

10. Zhao C, Ge B, Villena J, Robert S, Emily Y, Shaohua Z, David G, David W, Jianghong M. Prevalence of Campylobacter spp., Escherichia coli and Salmonella serovars in retail chicken, turkey, pork and beef from the greater Washington D.C. area. Appl Environ Microbiol. 2001:67(12):5431-6.

11. Bhandare SG, Sherikar AT, Paturkar AM, Waskar VS, Zende RJ. A comparison of microbial contamination on sheep/goat carcasses in a modern Indian abattoir and traditional meat shops. J Food Cont. 2007:18(7):854-68.

12. Arnaut-Rollier I, De Zutter L, Van Hoof J. Identities of the Pseudomonas spp. in flora from chilled chicken. Int J Food Microbiol. 1999;48(2):87-96.

13. Borch E, Kant-Muermans ML, Blixt Y. Bacterial spoilage of meat and cured meat products. Int J Food Microbiol. 1996;33(1):103-20.

14. Garedew L, Hagos Z, Zegeye B, Addis Z. The detection and antimicrobial susceptibility profile of Shigella isolates from meat and swab samples at butcher's shops in Gondar town, northwest Ethiopia. J Infect Public Health. 2016;9(3):348-55. https://doi.org/10.1016/j.jiph.2015.10.015.

15. Arnaut-Rollier I, Vauterin L, De Vos P, Massart DL, Devriese LA, De Zutter L, Van Hoof J. A numerical taxonomic study of the Pseudomonas flora isolated from poultry meat. J Appl Microbiol. 1999;87(1):15-28.

16. U.S. FDA: Bacteriological Analytical Manual (BAM). Center for food safety and applied nutrition. https://www.fda.gov/food/foodscienceresearch/ laboratorymethods/ucm200694.html. Accessed 22 Jan 2017.

17. Garrity GM, Brennner DJ, Krieg NR, Staley JT. Bergey's manual of systematic bacteriology. The proteobacteria, the gammaproteobacteria. 2nd ed. Berlin: Springer; 2005

18. Tassew H, Abdissa A, Beyene G, Gebre-Selassie S. Microbial flora and foodborne pathogens on minced meat and their susceptibility to antimicrobial agents. Ethiop J Health Sci. 2010;20(3):137-43.

19. Abdalrahman LS, Wells H, Fakhr MK. Staphylococcus aureus is more prevalent in retail beef livers than in pork and other beef cuts. Pathogens. 2015:4(2):182-98. https://doi.org/10.3390/pathogens4020182.

20. Rong D, Wu XuM, Zhang J, Yu S. Prevalence, virulence genes, antimicrobial susceptibility, and genetic diversity of Staphylococcus aureus from retail aquatic products in China. Front Microbiol. 2017;2017(8):714. https ://doi.org/10.3389/fmicb.2017.00714.

21. Kadariya J, Smith TC, Thapaliya D. Staphylococcus aureus and Staphylococcal food-borne disease: an ongoing challenge in public health. BioMed Res Int. 2014. https://doi.org/10.1155/2014/827965.

22. Chao G, Zhou X, Jiao X, Qian X, Xu L. Prevalence and antimicrobial resistance of foodborne pathogens isolated from food products in China. Foodborne Pathog Dis. 2007:4(3):277-84.

23. Rhoades JR, Duffy G, Koutsoumanis K. Prevalence and concentration of verocytotoxigenic Escherichia coli, Salmonella enterica and Listeria monocytogenes in the beef production chain: a review. Food Microbiol. 2009;26(4):357-76. https://doi.org/10.1016/j.fm.2008.10.012.

24. Lee JB, Han D, Lee HT, Wi SM, Park JH, Jo JW, Cho YJ, Hahn TW, Lee S, Kang $B$, et al. Pathogenic and phylogenetic characteristics of non-O157 Shiga toxin-producing Escherichia coli isolates from retail meats in South Korea. J Vet Sci. 2018;19(2):251-9.

25. Rantsiou K, Alessandria V, Cocolin L. Prevalence of Shiga toxin-producing Escherichia coli in food products of animal origin as determined by molecular methods. Int J Food Microbiol. 2012;154(1-2):37-43. https:// doi.org/10.1016/j.ijfoodmicro.2011.12.010.

26. Garedew L, Hagos Z, Addis Z, Tesfaye R, Zegeye B. Prevalence and antimicrobial susceptibility patterns of Salmonella isolates in association with hygienic status from butcher shops in Gondar town, Ethiopia. Antimicrob Resist Infect Control. 2015:4:21.

27. Lopatek M, Wieczorek K, Osek J. Prevalence and antimicrobial resistance of Vibrio parahaemolyticus isolated from raw shellfish in Poland. J Food Prot. 2015;78(5):1029-33. https://doi.org/10.4315/0362-028X.JFP-14-437. 
28. Yücel N, Balci S. Prevalence of Listeria, Aeromonas, and Vibrio species in fish used for human consumption in Turkey. J Food Prot. 2010;73(2):380-4

29. Kwan KK, Skura BJ. Identification of proteolytic pseudomonads isolated from raw milk. J Dairy Sci. 1985;68(8):1902-9.

30. Gennari M, Dragotto F. A study of the incidence of different fluorescent Pseudomonas species and biovars in the microflora of fresh and spoiled meat and fish, raw milk, cheese, soil and water. J Appl Bacteriol. 1992;72(4):281-8
31. Elmahdi S, DaSilva LV, Parveen S. Antibiotic resistance of Vibrio parahaemolyticus and Vibrio vulnificus in various countries: a review. Food Microbiol. 2016:57:128-34.

32. Gousia P, Economou V, Sakkas H, Leveidiotou S, Papadopoulou C. Antimicrobial resistance of major food borne pathogens from major meat products. Foodborne Pathog Dis. 2011;8(1):27-38. https://doi.org/10.1089/ fpd.2010.0577.
Ready to submit your research? Choose BMC and benefit from:

- fast, convenient online submission

- thorough peer review by experienced researchers in your field

- rapid publication on acceptance

- support for research data, including large and complex data types

- gold Open Access which fosters wider collaboration and increased citations

- maximum visibility for your research: over 100M website views per year

At BMC, research is always in progress.

Learn more biomedcentral.com/submissions 